Gadjah Mada International Journal of Business

January 2003, Vol. 5, No. 1, pp. 109-128

\title{
WHAT A FIRM TAKES TO COMPETE IN CONDITIONS OF ECONOMIC ADVERSITY
}

\section{Muyanja Sseyonga}

This article attempts to identify the key factors that underpin the success offirms in conditions of economic distress. Such factors encompass astute management with the skill and experience in a variety of competitive moves and maneuvers; adoption oflow-cost-low price strategies; more use of scenario planning rather than mere replication of past company actions; sufficient liquidity to exploit opportunities availed by economic downturn; and exploiting the advantages of knowledge management. Better incorporation of information technology, proper use of currency risk management methods, smart globalization that incorporates both government and nongovernment elements, favors the formation of joint ventures with local businessmen, and investment of ample time in the understanding the customs, values, and traditions of local societies elevate company's competitive advantages over rivals which enhances the company's capacity to deal with economic distress. It is incontrovertible, however, that the success offirms must be backed by strong and appropriate macroeconomic management by governments with respect to fiscal, monetary and trade policies

Keywords: core competence; economic distress; globalization; knowledge; outsourcing 


\section{Introduction}

Today's firms face many unprecedented challenges. The pace of change driven by technological innovations has shortened production cycles and transformed production processes, which has made decentralized operations more feasible than ever. The implication is that the definition of competitors any firm faces is ever widening as the distinction between domestic and foreign firm blurs. Firms have to brace themselves for stiffer competition in their domestic, let alone in the foreign market. This is coupled by an increasingly dynamic and complex economic environment, which has come in the wake of financial deregulation; increasingly diverse and complex consumer demands; and the increasing use of state of the art marketing approaches.

In order for firms to remain competitive, they have no option but to strengthen their core competences, which can only be done by carrying out strategic reappraisal intended to re-orient the strategy in order to match with the current state of environmental contingencies. Inevitably the new strategic orientation induces structural transformation that encompasses overhauls in management styles, production processes, work rules, norms and values and customs, human resources recruitment, selection, education and training, appraisal and evaluation; and adoption of new perspectives on suppliers, consumers and other firms in the same line of business.

Apparently, organizations are compelled to undergo transformations if not to expand their market share, at least to survive. The main objective of organizational transformation is to induce new capabilities, as well as revitalize existing ones with the objective of re-establishing the fit and match between strategic and environmen- tal contingencies on one hand, and organizational structure, on the other, to ensure maximum effectiveness (Kimberley and Rottman 1987). Much has been written on management of organizational change, which has provided readers with a catalogue of success factors, discernable in firms that able to 'stick their heads out of the pack' with renewed confidence.

Yet, the fact that not a few managers of organizations both large and small, new and old, in processing, manufacturing, and service industries, in extraction as well as in agriculture, fail to steer their organizations from the state of ineffectiveness when the organization's strategy, structure, and culture are diametrically opposed to the demands of the environment, is livelier today than ever before, possibly thanks to the aftereffects of the 1997 ASEAN-4 economic crisis which has been compounded by ongoing economic downturn. The fact that many enterprises succumbed to the crisis provides the backdrop underlying this study. Specifically, the main objective of the article is to make an attempt to identify some of the key factors that distinguishes the relatively few firms that managed to ride the tide from the majority which were overwhelmed by the current. By so doing the article will help in identifying major factors that explain the poor performance of most, where a few excelled, and the extent to which lessons from the recent experience can be made use of, in future as especially as regards managing organizations through crisis situations wherever and whenever such 'raise their ugly heads'. Section two considers the obstacles that stand in the way of organizational change, which is followed by section three that discusses the imperatives for change. Section four considers the problems that may arise in the long term from policies that prove profitable in 
Sseyonga -What a Firm Takes to Compete in ...

conditions of economic adversity. Section five presents the concluding remarks.

\section{What Factors Inhibit Firm Response to Environmental Change?}

One cannot comprehend the factors underlying the success of some firms under adverse economic conditions, without at the same time delving into the dynamics of factors that hinder firms' response to changes in the economic, social and technological environment. A number of factors are responsible for the slow adjustment of the firm to changes in the environment.

The main obstacle to organizational adjustment and change ironically is attributed to the characteristics of the firm that enable it to provide sustainable, reliable products and services, which translate into high predictable profitability. These come by way of investment in equipment, specialized personnel, successful strategies which are institutionalized into standard operating procedures and practices that influence firm routines, and create internal vested interests to support them at all costs; organizational history, which justifies past action despite changes in environmental condition, which stand in the way of alternative strategies, limitations on internal information received by decision makers as it has to be filtered by those with vested interest to keep things as they are. Those holding resources and power in an organization fear change because it is expected to render performance less reliable, reduce organization's survival chances, likely to divert resources from operating to re-organizing, and most likely to reduce operational efficiency. The powers that be go all the way to forestall any attempts that may be envisioned to change the status quo by preventing vital external information on economic, social, and legal environment, from reaching key decision makers, fearing that the knowledge there of might lead to the institutionalization of change.

In a similar vein the longer the firm is established the harder it is for it to adjust quickly enough to changes in both its internal and external environments. This is due to the larger bureaucracy that evolves over time to run the firm, putting in place, as it were, rigid impersonal rules and regulations, hierarchical strata, development of non hierarchical power, all of which come into prominence with increasing size and age (Haveman 1992). With time, 'theway-we-do-things-here' mentality evolves, which gradually crystallizes into values, norms, attributes, and the core of corporate culture. This is harder to change since it underscores the very philosophical, historical, emotional and sentimental foundation of the firm.

The larger the size and age of the organization, all other factors remaining constant, the more the availability of slack resources which prevents taking quick remedial actions. Moreover, large firms have institutional contacts, which protect them from competitors. These may include government regulations, trade polices, and belonging to exclusive business associations it should thus be noted, as firms become reliable performers over time, any course of action that once led to success is institutionalized into routines, which is meant withstand any attempts to change. Change is considered disruptive to old, long established firms; hence risk of failure is higher in old firms than in new ones (Amburgery et al. 1993).

Yet under conditions of substantial change, adjustments in organizational structures and activities are not only ben- 
eficial to short run financial performance but are imperative for the long run survival chances of the firm.

\section{Imperatives for Organizational Change}

To delve into the dynamics of organizational change, it is imperative to consider various theories, which have been propounded on the subject by a number of prominent scholars. The most prominent theories include structural-functional, contingency, and strategic choice.

\section{Structural-functional Theories}

Structural-functional theories expounded by Blau and SchoerHerr (1971) attribute the necessity for organizational transformation to the need to restore organizational effectiveness through re-establishing the state of equilibrium between the organization and the environment, disturbed by exogenous forces (Donaldson 1987). The transformational process involves the adoption of a new strategic orientation, which is the stepping-stone for instituting structural change. It is thus expected that the establishment of a new equilibrium should restore organizational effectiveness reflected in improvements in performance. The emphasis here is on the existence of a divergence between exogenous forces (the external environment) and the organizational structure, which leads to organizational ineffectiveness. One would expect most organizations in Indonesia for instance, to undergo transformation in response to high rates of technological innovations, which affect product design, production process, distribution and marketing; in the wake of 1988 banking deregulation; and as an upshot of the 1997 economic crisis (Sadli 1998; Cole and Slade 1998; McLeod 1998).

\section{Contingency Theories}

Lawrence and Lorsh in Donaldson (1987) and Child (1972) explain organizational transformation as a response to the pressure exerted on the organization by either intra-organizational, environmental contingency forces or both. While intraorganizational forces are manifested in the size and technology level in the organization, the environmental forces represent the rate of technological change prevalent in other organizations serving the same sector. Structure follows contingency. Change in the contingency either from within or outside the organization produces a direct and immediate change in the structure. Change does not only originate from the external environment but also from inside the organization. The important element here is the existence of low performance, which might be due to either incongruence between internal systems and networks, comprising the organizational structure, and the environment. Organizational transformation, according to contingency theory, can be influenced by the political dynamics within the organization, rather than a mere reaction to the dictates of the environment. Strategic choice as expounded by Child thus, in addition to factors conventionally regarded as crucial, considers other factors such as values, perceptions, and political influence of organizational actors in the determination of structure. This may explain why for example, Bill Gates III, Chairman of Microsoft, spends US\$30 billion to strengthen his company's standing by making the programming code as complicated as possible to deny rivals in software programming to use his Windows program platform. The dominance in operating system, with Windows program loaded on 95 per cent of PCs sold, is extended to “... game consoles, small business soft- 
Sseyonga -What a Firm Takes to Compete in ...

ware, and Web services." The PC industry is thus locked in as are Microcomputer software producers (Business Week June4. 2001).

\section{Strategic Choice Theory}

The mismatch between structural contingencies and environmental contingencies results into low performance. This low performance in turn induces pressure for change in to restore organizational effectiveness. The match is restored through the adjustment of structural variables to environmental contingencies. The adjustment of the structural variables does not necessarily imply following the 'dictates' of the environmental variables. Contingency variables can be manipulated to retain the structure preferred by the dominant coalition in the organization, a view diametrically opposed to contingency determinism (Donaldson 1987).

\section{SARFIT (Structural Adjustment to Regain Fit) Theory}

The theoretical underpinning of SARFIT theory considers a change in the contingency variable (size, or degree of diversification) as causing a mismatch between the existing structure and the new value of the contingency variable (Donaldson 1987). The match is specific to any particular pair of contingency and structural variables (size and specialization, product diversification and divisionalization). The mismatch between the contingency variable and structure leads to a range of dysfunctional behaviors in organizational systems that include: slow and poor quality decision-making, miscommunication, and demoralization. Such conditions in turn engender low economic performance, loss of opportunities to gain sales, low profitability, and low returns to shareholders. Low firm performance cre- ates pressure on the dominant coalition in the organization to reorganize. With reorganization in tow structural adjustment is made, and the fit between environmental and structural contingencies is restored, may cause performance to rise.

\section{Rational School of Thought Theories}

The organizational transformation is attributed to the ability of management to perceive signals of a changing environment, recognize strategic options available and make appropriate decisions. This process is influenced by on one hand, by the state of environmental conditions, and on the other, the feedback effects from prior performance (Ginsberg and Forbrun 1989). This stance presupposes that all aspects of the transformation process are under the tutelage of management. Management has to correctly perceive the signals of a changing environment, which should enable him to take appropriate actions towards initiating and implementing the transformation process.

\section{Cultural School of Thought Theories}

Organizational transformation is a consequence of changes in strategic change that occurs because of changes in strategic formulae managers employ in their construction of the environment. The need for change occurs when new frames of reference take place among managers that indicate need for realignment of the strategic position of the organization. The focus in this viewpoint is the effect of the change in environmental contingencies and the current state of structural contingencies on the perception of management. What is vital is that changes in environmental contingencies impact on the formation of the manager's new frame of reference. Thus the source of transformation is the change in environmental contingencies in relation 
to the state of structural contingencies as perceived and conceived by the manager.

The aforementioned theories in the main attribute the organizational transformation process to attempts at restoring organizational effectiveness. The forces that induce organizational ineffectiveness arise from within and outside the organizations. Changes in structural contingencies such as size, increasing diversification, change in management style, and low technology applications may lead to organizational transformation. On the other hand, exogenous forces, such as declining consumer demand, falling production and rising unemployment, higher rates of technological innovation (Quinn 1995), increasing competition arising from economic deregulation (Nasution 1995), and the economic down-turn compel some firms to collapse while at the same time allow the entry of new players.

The main source of firm success operating under conditions of economic distress lies in controlling all costs that go into the production, distribution, and sale of a product or service, without necessarily compromising essential product quality attributes. There is no better company better at this strategy than DELL Computer. The company developed a low cost pricing strategy, which was executed through increased efficiency in production and marketing, which enabled it to sell products at lower prices than rivals. Increased revenue obtained was used to enter into new markets by selling personal computers at prices as low as a third of those offered by competitors who went for higher profit margins where DELL sought for higher market share. In line with the strategy, nonessential staff was laid off, computerization of key company functions and extensive and intensive use of the Internet took center stage.
Much in line with this strategy, DELL unlike its competitors, invested little in Research and Development, banking instead on software giant and Chip producer Microsoft and Intel, respectively, to supply the company with the latest technology in applications software and processing power (Business Week -September 24. 2001). This enabled the company to cut the cost of production markedly compared to rivals. The upshot of all this was increased capacity to sell computers at prices which competitors such as Compaq could not beat, which provided DELL with the leverage to enhance its their market share at the expense of beaten rivals. Adopting a low cost strategy did not induce DELL to shy away from brash advertising, knowing well the importance of intensive advertising in the rapidly changing informational technology industry, especially for late entrants (Kerin et al. 1992: 43-44). Through such advertising campaigns against computer maker Compaq in 1993 for example, DELL was able to increase her market share from a mere 4.1 percent to 18 percent between 1993 and 1999. Such measures equipped the company with sufficient cash by the time economic slowdown struck, which was used as a cushion to offset low prices charged on personal computers and computer servers during the 2001 price war.

The effectiveness of the strategy adopted by DELL is reflected by the staggering profit, which amounted to US \$361 in 2001 , from $\$ 18$ billion of sales, that at a time when the industry as a whole posted US $\$ 1.1$ billion losses, increased market share which rose from 4.1 percent to 18 percent between 1993 and 1999. In addition, as testimony to its success, DELL became number one producer of PCs in 2001 with a worldwide market share of 13 
Sseyonga - What a Firm Takes to Compete in ...

per cent, which is a rough measure of the extent to which the company's no-frills, low-cost pricing, efficiency-is-king strategy brought the company immense bucks for the bang. Indeed, "anyone can look like a genius on the way up, a lesson that eluded the attention of Dotcoms, but on the way down, you need a fix on details and the willingness to move fast," aptly remarked Seibel Systems Inc., CEO Thomas M. Siebel concerning the necessary arsenals for a company to survive economic distress (Kerstetter 2001: 63). Explicit in Seibel's remark is the idea that one of the hallmarks of firms that outsmarted the economic downturn was their ability to keep track of the real demand for the company's product as opposed to what was demanded by middle-men, which under economic boom, may be distorted by panic ordering. The real demand by end users of a company's product is important, but equally so is the consumer's financial soundness which is reflected in deal closure rates, payments, and trend of receivables.

It is also important to identify other factors such as incentives, which are likely to misrepresent real demand such as price cuts, trade and cash discounts. Observing forecasts on consumer confidence, and economic output figures can give guidance on the probable business trend, constant scrutiny of sales closure rates and hiring costs can give the rough picture of the trend down the line, which equips enables the company to rein in costs before the crisis strikes. Siebel's success was underpinned by its masterly at reading the import underlying economic signals, and rapid pace in executing the plan of action. Siebel's financial planners for example, put up four contingency budgets which enabled the company to lay off 10 percent of its work force in time, postponed bonus payments, cut travel expenses, cut recruitment costs, reinforced sales staff to increase closure rates, and created special teams of executives and technical staff to push up sales. The result of such efforts was an increase in quarterly returns and doubling of profits in the year 2001, at a time when other companies were barely breaking even (Kerstetter 2001: 62). Another example is DELL Computer, which increased its direct contacts with retail and corporate consumers via its more than 60,000 virtual stores on the internet, where orders are taken directly from customers. With orders taken directly from consumers, DELL was able to enhance the reliability of consumer demand forecasts, lessened his production cost as he did way with distribution charges, and reduced the necessity to borrow cash for working capital purposes as cash had to be collected 30 days before orders were met. Such measures strengthened DELL competitive strategy as a low cost, low price computer producer.

Maintaining continuous and consistent innovation in product, process, operating procedures, and business routines is necessary for ensuring the emergence of a consistently adaptive, and learning organization. This is necessary if the organization is not only to remain competitive but also to lead the pack for some sustained time, essential for acquiring substantial market share. This is because innovation yields new products, new techniques, new technologies, and new methods of operations, which increase the competitive edge of the firm against rivals (Starbuck et al. 1995: 393). In dynamic and complex environments, with as many and diverse customers as competitors, the maxim is to constantly and consistently review product performance, methods, and polices used in attracting customers as well as 
outmaneuvering competitors, if the company is to stay in the lead. To achieve the aforementioned is no easy feat, and requires an organization with time, new product, volume-mix flexibility capabilities (Suarez et al. 1995). This is precisely what has made Nokia Corporation to maintains its leadership in the Cell phone sector. The company spends close to US $\$ 2$ billion each year on research leaving rival cello phone companies such as Ericsson, Motorola, and Siemens, to name just a few, mere followers in its tracks. That explains why the performance of Nokia, though experienced some decline in the wake of the 2001 economic contraction, continued to outperform its rivals in terms of market share, and new product releases.

Flexible firms are found to have programmable technologies, production management techniques, such as Just In Time, which enable such firms to have low, machine set-up times, higher worker participation in production process, handle more complex mix and make it easier to introduce new products. Success is also attributed to increased volume flexibility, closeness of the relationship between the firm, on one hand, and its suppliers and subcontractors, on the other, and use product development process that employ design for manufacturability principles (Suarez et al. 1995). There is possibly no company better than Toyota Corporation in this regard, the number one car producer in the world. The company achieved such status thanks to its to consistence in making innovations in production process, inventory (Toyota being the founder of Just-InTime inventory management practice), marketing, and using experienced and skilled employees to combine quality and mass production. Enhanced efficiency was manifested in lower production costs, short lead time, higher quality products, a large number of car models (60 in all), which enabled the company to increase its share in the international car market. This feat was achieved in both the ordinary and luxury car market segments, to the extent that the Toyota has been able to substantially dent into market shares of the likes of Daimler-Chrysler, BMW and Jaguar (Business Week -September 24. 2001).

Companies that are able to outsmart others in hard times are generally led by proficient and astute top management. Managers of such companies invest in the future by focusing on the long-term competitive position, which may be lost to rivals if there is lapse in investment in hard economic conditions. Long term profit margin on investment over financial cost takes precedence over financial risk in conditions of economic distress (Ghemawat 1992). Such management is awash with experience acquired over time through using a multitude of competitive methods in good as well as in bad times, making management accustomed to planning and executing competitive changes. The internal company environment is also supportive of quick adjustment to changes by providing management with the requisite raw materials, manpower, and money, vital for carrying out frequent competitive changes in a dynamic and diverse market environment. Through the conduction of frequent competitive changes that are driven by changes in either customers' tastes or competitors' actions or both, management acquires deep knowledge and broad perspectives on the pertinent competitive strategies on product improvements, advertising, strategic alliance formation, how to generate certain reactions from rivals and customers. Management also acquires the knowledge on the alternative ways of serving existing and attracting new customers using a repertoire 
Sseyonga -What a Firm Takes to Compete in ...

of the company's actions and reactions in a variety of situations acquired over time.

It is this reason that underlies the success of long established companies such as big blue IBM (International Business Machines), DU PONT, Procter and Gamble, and Microsoft corporation at withstanding hard economic conditions than upstarts, the likes of the many Dotcom companies that sprung up in late 1990s. Management in the former companies has been tested and tried by a variety of economic conditions, exuberant and lethargic, alike, which equipped them with the knack, the knowledge, the vision, and the sense of dealing with whatever situation the company faces.

Many, a company that succeed in economic recessions changes their top management in time, once old management is found to falter, procrastinate, or not all equal to the task. Long experience and masterly of 'tried and proven' strategies and tactics which bring windfalls in stable conditions become obstacles to much needed regeneration in conditions of economic meltdown. This is because crisis situations need not only knowing well how to maintain continuity in the organization by observing material flows, reports, planning documents schedules, and blueprints, but equally important, if not more so, is the ability to maintain the morale and enthusiasm, induce new beliefs, goals, values and ideas among employees in the organization. This is crucial for carrying out successful reconceptualization of the organizational environment (Starbruck 1995).

What is likewise undeniable is the fact that firms operating in sectors or industries that produce necessities of life such as food stuffs, clothing, sanitary ware, and house ware perform better in adverse economic than those coined new economy industries such as information technology. Enterprises that deal in foodstuffs and the related products, clothing, essential utilities such as energy, water, and sanitation are slightly affected by economic downturns, if at all. Agriculturalsector-related enterprises were also posting unprecedented profits. On the contrary, companies in the computer industry encompassing software, chipmakers, storage producers, and computer servers, and telecommunications industry (cell phone sector in particular) were linking their wounds in the aftermath of the economic crisis. Apparently, the traditional industry, having been tested by time and events, has learnt to adjust itself well to any economic battering, however severe. This could be attributed to the immense and invaluable experience managers of such firms acquire over time, which enabled them to develop requisite competitive actions and reactions as situations demand. It is incontrovertible too, that the low demand elasticity of products in some traditional industries for example foodstuffs, explains to a great extent, the slight reduction in revenue posted by firms operating in such sectors, hence their ability to withstand adversity quite remarkably.

Such firms also show high dexterity at diversifying away from original domains by investing in only in new activities that are related to the organization's existing core competences. This averts the necessity for strong overhauls in operations and administration, which would envisage major strategic and structural reorientations that would not go well with key vested interests in the organization. Such diversification strengthens firms' financial performance by enhancing economies of scope in research and development, production, and marketing. Moreover, with diversified sources of revenue 
such companies are able to offset losses incurred on some products by returns from other products, which are not as adversely affected by the economic situation. This was exemplified by Dell's diversification from building and selling PCs to computer servers, storage, network, all of which are not far removed from the core industry (Business Week-September 24.2001:55). The same story holds for Microsoft's diversification into consoles, networking software, and personal digital assistants. This partly accounts for the good performance of such companies even under conditions of dire economic doldrums.

What is also likewise incontrovertible is the fact that firms with long track records on customer satisfaction prevail under all economic conditions, adverse and vibrant alike. Investing in customer satisfaction is achieved through sustained investment in quality assurance which wins over customer's loyalty, reduces customer's price elasticity hence insulates them from competitive efforts. Satisfied customers do not desert the company easily in hard times, which can be exploited by the firm to charge higher prices under good and adverse economic conditions than it would. Customer satisfaction enables the firm to expand its market share and maintain the existing one, with little costs. Profitability will therefore be ensured in the long haul thanks to good quality products or service which in turn ensured customer loyalty arising from the cumulative satisfaction they derive product use, and experience (Anderson et al. 1994: 55)

Companies 'of all seasons', if one may call them, have time tested astute management of customers through the offering of a full range of products, a capability known as commodity bundling (Lawless 1991: 270). By bundling products or services the company is able to lower the cost of production and delivery, increase its differentiation leverage over rivals, and increases its grip on customers' loyalty. Achieving the foregoing shores up the firm's competitive advantage and heralds market share enhancement. Through the bundling of products and services, the firm locks in the customer, by reducing his susceptibility to competitors' advertisements as a result of an increase in switching costs. The company is thus able to charge higher than average prices, which strengthens its liquidity and competitive edge over rivals. Such customers find it hard to switch from one firm to the other, even in adverse economic conditions.

There is no better example of this than Microsoft Corporation. The company bundles almost all software applications on its windows program, locking in the PC producer and owner to software packages produced by the company and those with arrangements with it. The customer who buys a computer has little choice but to buy windows program, in which almost all the application programs he needs in his day-to-day chores are incorporated. The company's revenues may slightly fall due to fewer compute s bought yet the services on applications already installed on old computers continues to bring in returns.

Many companies take the bundling process further through the creation of captive demand for the product as well as offering the services related to it. The rationale underlying this notion is that while demand for the product may experience high and low, demands for the service is relatively inelastic and predictable and therefore offers assured returns to the company. It is the provision of service that 'smoothes over rough spots between innovations' and enables the company to tide over downturns as the service business is 
Sseyonga -What a Firm Takes to Compete in ...

inextricably linked with product use. Product service business brings long-term contracts, which yield predictable revenues. "Product service is a long-saving fall-back when times get tough" (Weber 2001: 62). Cell phone companies such as Ericsson being aware of this do not only concentrate on cell phone development and production, but also invest huge amounts in cell phone accessories and network cell phone software development, which have relatively inelastic demand than the main product. Ericsson is the major cell phone network software producer, which ensures more predictable returns than the sale of cello phones for the company, which enables it to weather the storm better than rivals.

The nature of business planning has an important bearing on the ability of the company to prepare itself for either the rainy day or for 'windfall' profits. Companies, whose operations are underpinned by serious scenario planning, employ different perspectives to determine all potential eventualities, which aptly prepares the organizations for any economic conditions. Managers 'construct' scenarios, which explore the joint impact of various uncertainties, showing the possibility of each, and how the firm must prepare for all the eventualities (Shoemaker 1995). Scenario planning equips the firm with the ability to identify early warning systems, assessing robustness of core competences, generation of better strategic options, evaluation of the risk-return of each strategic option, taking consideration of uncertainties, and serve as pointers for the need for to change (Shoemaker 1995: 34). Small wonder that such companies are as prepared for an economic downturn as they are for an upswing. DU PONT, the renowned US based house equipment manufacturer, is one such company, which en- sures that all likely scenarios are incorporated in the company's plan of actions, making it easier for the company to deal with any economic situation as and when it occurs. The company desists from using past gains as the basis on which to make projections of the future plan of actions, the folly of many companies, but scenario planning which is based on cautious observation of macroeconomic indicators such as trends in consumer confidence, energy prices, and interest rates.

The digital era is with us, which implies that the company that successfully incorporates the internet into its core business operations enjoys the most return on the investment made. The benefits become more evident in an economic downturn. Using the internet offers a myriad of leverages over rivals, encompassing quick product diffusion, capability of focusing on niche markets for companies specializing in niche products by increasing the critical mass of customers; easier expansion into new markets through quicker adaptation to customization through online surveys, bulletin boards, tracking web visitors, advertising measurements, and use of customer identification systems, and email marketing lists.

Companies use the internet to consolidate their core competences by enhancing links with suppliers, customers, outsourcing nonessential functions, and contract manufacturing, which enables them to cut down on their overhead fixed costs (Quelch and Klein 1996). In order to achieve optimal internet effectiveness, a good number of firms use collaboration software technology to share information and streamline purchasing, enables them to cut on product design and development costs, facilitate simultaneous development of product designs, and helps employees and business partners work together to 
make products faster and more cheaply. This is because the internet equips the firm with three important network capabilities (Quelch and Klein 1996). Using 'one to many' network enables the firm to communicate policies and market needs to other divisions of the company; using 'many to one' network enables the firm to seek and acquire information from divisions as well as individual employees; and using 'many to many' networks, the firm is able to use real time, synchronous discussion among all the units. This reduces machine set up time, reduces lead time, increases the pace of the firm's response to changes in internal and external environmental contingencies, features that equips it with the capability to deliver better new products and services faster than rivals.

There is no better example of this breakthrough than Procter and Gamble. The company uses collaboration technology corporate standards system software to manage its research and development activities. This is achieved by linking farflung drug researchers, the 900 factories all over the world, 17 product development centers in 73 countries, which produce 300 brands valued at $\$ 39$ billion a year. Ford Motor Company is yet another firm that uses the internet to "complement, rather than contradict' its core competences. Ford uses 900 virtual work spaces to design cars and hold meetings, which saves time, energy and money, which enables it to react quickly to any new information on product design, demand, or competitors' maneuvers. SCI company uses Agile software to connect its employees, customers, and suppliers together in its four factories, which enable her to considerably slash production costs, increase productivity, and shore up the bottom line (Ante 2001: 95).
Dell Computer outsold her rivals by not only lowering production costs, but also compelling suppliers to get 'wired directly with his factory floors', which meant that inventory was made to the level of quality demanded, kept at a minimum as it could be replenished on demand, and reduced demand for working capital. Moreover, few days of inventories in stock enabled Dell to take advantage of better technology at lower prices, which provided a huge shot in the arm of its barebone strategy. Toyota, the number one car producer in the world uses virtual workshops to quicken designs, which enables it to cut margin of error to the bare minimum, short lead time of under 12 months where rivals take $24-30$ months, low costs on prototypes and enables it to produce more than 40 models. Thus, in order for a firm to excel, both in a boom and downturn, it should have the capacity to sustain sound revenue for a long span as well as the ability to integrate information technology in all the operations, both technical and administrative.

Companies that succeed in recessions, slowdowns and downturns, incorporate information technology into the companies' core competences rather than considering it as separate, detached, if incompatible unit. The internet for example, is incorporated into the existing company core competences, which enables it to differentiate its products or services better than rivals. The Internet, according to management guru, Porter, 'should help in integrating service, sales, logistics, manufacturing and suppliers,' which facilitates the reduction of transaction and inventory costs, thus increasing the company's competitive edge over the rivals'. The internet is also used by successful companies to carry out joint product design among the 
Sseyonga -What a Firm Takes to Compete in ...

company, consumers and suppliers. This explains why companies that use the internet to outsource almost everything from manpower recruitment to information system development, the likes of Cisco systems, though rein in on costs in the short run, compromise on their core competences, which is why they lose out to rivals in the long run. Outsourcing key company functions to suppliers increases its vulnerability to competitors' predatory practices by making their products and systems more generic than differentiated (Byrne 2001: 64; Engardio 2001: 82; Weber 2001: 58).

Many companies, such as Rand Corporation, Aerospace corporation and A.D. Little Management Consultancy and other knowledge intensive firms do not feel the effects of downturns and recession because they employ esoteric expertise, which injects exceptional knowledge into firm's routines, job descriptions, plans, extraordinary strategies all of which are crucial in the production of differentiated products unlike others in the market which rivals take time to emulate, if at all (Starbuck 1992: 716). Knowledge intensive firms also have immense knowledge embedded in capital equipment, financial instruments, as well as in unique firm routines and professional cultures which encourage 'conflict' and competitiveness for the firms' projects among the array of experts, increase the quality, diversity, and uniqueness of products produced by the firm, factors that enable such firms to develop 'distinctive competences mirrored' the circumscribing environments' peculiar needs and capabilities all of which strengthen the firm's ability to adapt to social, economic and technological changes (Starbuck 1992: 719-721).

Rand Corporation employs its wealth of experts in the analysis of policies, draw- ing recommendations, and in the development of alternatives that are forwarded to policy makers in USA government and the military. Such services are unique and require extraordinary expertise to execute, as well as needed all the time irrespective of the 'state of the economy'. A.D. Little consulting firm, in a similar vein uses its expertise to produce diverse products in areas of technology, operations management and strategic planning, and economic development, products with wide spread demand, equip the firm with the capability to withstand any shocks in the economy.

Keeping constant track of macroeconomic factors for signals of the underlying trend or future prospects, is another hallmark of firms that outperform others in economic downturns. This is why the availability of skilled manpower resources which can read the numbers well, a precondition for making informed judgment on what should be the best plan of action, is an absolute necessity. This partially underlys the success achieved by DU PONT which made use of its wealth of experience and skilled personnel to keep track of oil prices, exchange rates, inflation, and monetary authority policies knowledge that enabled the company to discern declining business activity before it actually occurred. Quicker and better reading of the economic signals enabled the company to apply brakes on production and inventory orders just in the knick of time, which activities reduced potential losses preparing the company for a softer landing than others (Weber 2001: 60).

There is neither enterprise nor country that can avoid the impact of international trade and globalization. This is because of the advantages that come with the two world trends. The increasing flow of goods and services, investments, and factors of production bring with it higher 
incomes, technological transfer and innovations, higher human resources development, higher productivity, all of which translate into higher social welfare and prosperity. This underscores the importance attached to smarter globalization by enterprises, which outperformed others despite the advent of the crisis. Such firms invested a lot of time and energy in developing deeper understanding of local business practices, involved local officials and NGOs in their activities right from inception, which reduced the risk of expropriation and backlash. Notable also was the nature of investments made which were small but focused avoiding mega projects. An example of such project was Citibank's Suvidha in India under which trucking companies were persuaded to open retail accounts for their employees with Citibank in return for saving, credit, and checking account services. The success of such an endeavor is seen in the increase in the number of clients by 200,000 , which by no means a mean feat in an emerging market.

It is also indisputable that firms that outperform competitors during downturns or recessions make use of local leverage through the use of existing distribution networks and underutilized factories, which make it easier and cheaper to establish their presence in new markets without exposing themselves to higher economic risk. A good case in point is Kodak's Expresses in China, involving the cooperation between Kodak and local banks under which the latter extends credit to film developers, while the former leases film development equipment to small entrepreneurs. Through such small ventures Kodak was able to increase its market share to more than 60 percent. This was at a time when the now defunct ENRON was getting her fingers burnt in India with its
US $\$ 4$ billion mega power project hitting stony wall.

On many occasions, smarter globalizes work jointly with local businessmen taking advantage of the wealth of experience, knowledge and customs of the local business environment the latter have. Involvement in global production and sell of products brings immense rewards in terms of larger market share, opportunity to diversify products and spreading of country risk, and wider access to skilled manpower from many countries available at wages lower than in the domestic economy. Globalization enriches company technology by incorporating local technologies in product development, production process, and product designs, and marketing. It also provides a wider source of financing as decentralization of production to various countries and reduces local subsidiary's demand on the parent company's financial resources being able to raise funds from local sources.

The increasing pace of globalization and international trade however, imply that active currency risk management should be part and parcel of a company's obligatory plan of actions if the company is to maintain its grip on its clientele as well as make inroads in new territories. Flexible exchange rate regimes reduce the cost borne by the monetary authority in terms of huge amount of money in interventions to ensure the exchange rate stability under fixed and managed floating regimes, however it exposes to transaction, translation, accounting, as well as economic risk. Thus, firms have to put in place mechanisms that protect their earnings from exchange rate volatility, which has increased over the past decade as a consequence of decisions by almost all countries to float their currencies. 
Sseyonga - What a Firm Takes to Compete in ...

It no small wonder that companies that ride the tide of economic doldrums, more often than not, are actively involved in exchange rate risk management, adopting various methods to protect their earnings from various sources of exchange rate variability. The most often used physical products, which have an actual cash flow, include: forwards, forwards-forwards, spots, short-term and long term physical swaps; while derivatives, which have a notional rather than an actual cash flow, include options, currency swaps, caps, collars, and floors (Batten et al. 1993). Such methods protect the company's assets and liabilities, which enable them to stem the tide of the downturn, as well as take advantage of an economic boom. The mishap of not adopting active currency risk management underlay the dramatic upsurge in enterprise and banking institution insolvency that hit Indonesia in the wake of the 1997 economic crisis. As the local currency hit record lows of Rp13,000 per US Dollar in 1998 liabilities in form of offshore loans denominated in dollars became millstones around firms' necks, and that at a time when assets denominated in local currency lost much of their real value as inflation got out of control (Sadli 1998; Cole and Slade 1998).

If the importance of skilled and flexible personnel is vital for the success of companies under normal conditions, they are an absolute necessity for firms under economic distress. It is such manpower that provides the necessary reliable demand estimates based not merely on past trends but through scrutiny of macroeconomic indicators, customers' payments, closure rates, competitors activities, as well as using the knack acquired during long spans on their jobs to know the tastes and preferences of customers. Skilled personnel have the flexibility that eases re- training which is necessary for adopting new technologies. Moreover, it is skilled personnel that provides the firm with the capacity to out compete rivals by carrying out innovations in process, production, operating procedures, product research, design and development, as well as in marketing (Business Week-September 24. 2001: 54 and 63; Kerstetter 2001: 63). Possession of skilled manpower by the company is the linchpin to successful involvement in global trade. If confers on the company the capability to attract partners in international trade and strategic alliances which is influenced by the level of organizational skills requisite for coordinating raw-material procurement, production process, distribution network, marketing, and after sales service spread in many countries.

Perhaps the best example is Procter and Gamble (P\&G) whose production facilities are spread in 900 factories and 17product development centers in 73 countries. Making use of her skilled manpower, simultaneous development of designs is made in several development centers which gives her the edge over rivals in lead time, prolific release of products, and in speed of response to both local and global demand changes. The alliance between Sony and Ericsson in cell phone production which was motivated by the necessity felt by both companies to control Nokia's dominance in the sector, was underpinned by Ericsson's superiority in cell phone network software and Sony's Multimedia capabilities, the combination of which would increase their leverage in third generation cell phone technology. Doubtless, the building of such capabilities is squared attributable to skilled and experienced manpower found in both companies.

If cost reduction is critical to the success of the firm in economic down- 
turns, so is the company's liquidity level. It can even be argued that the underlying reason for adopting a cost reduction strategy under recession is to ensure that the firm has sufficient cash resources at its disposal at such hard times. The boon of having ample cash resources under adverse economic conditions includes the ability to buy off solvent but illiquid firms (the acquisition of Compaq by HewlettPackard recently is a case in point), invest in brash advertising to increase the company's market share at a time when other firms are rolling back expenses on such activities, and repay commitments at discounted rates as creditor companies try to mobilize all the available resources to survive the downturn. Thus, companies awash with cash tend to outperform those with meager cash resources in conditions of economic hardship.

It should be noted that effective enterprise management could only succeed in conditions of good macroeconomic management. This is why the nature of policies adopted by the government and its agencies bear greatly on the success achieved by enterprises. The state does not merely serve as a back-up of whatever firms do, but also puts in place proper and prudent regulation and supervision of the private sector activities to avert the danger of bad decisions, which by and large impact on the entire economy. It is no small wonder that some countries such as Australia have gone as far as obliging the monetary authority to maintain constant contacts with key firms in the economy on matters concerning the direction of interest and exchange rate, as well as offering guidance on foreign activities firms are engaged in (Batten et al. 1993). This therefore underscores the need for enhancing the capabilities not only of the enterprises to meet the challenges of the increasingly global environment, but also those of the state to ensure better macroeconomic stability, transparency and accountability, the pre-requisites for sustained growth and prosperity (Hakimian 1998: 25-28).

The role of the state in today's business world can no longer be relegated to the place prescribed by the likes of Adam Smith, for contrary to expectations, the invisible hand, cannot steer the modern economy, unaided, to prosperity, under the best of economic conditions. This is even less so under economic conditions of economic crisis. Good enterprise management can be jeopardized by poor macroeconomic management, and the reverse is also true. Companies with good strategies fail to survive hard times if governments adopt unfeasible wage policies for example, high real minimum wages in times when prices are controlled which erodes firms' competitiveness (Osband 1992) and adopting expansionary fiscal policies without appropriate measures to develop the financial sector, which crowds out private investment. The state may also by firm management when it adopts stringent banking regulation policies ostensibly meant to reduce financial system vulnerability which ends up making it more fragile as monetary authorities are proscribed to lend to failing financial institutions preferring liquidation instead, high capital adequacy ratios that reduce the attractiveness of deposits, undermining the credit creation capacity; asset evaluation techniques which downgrade bank asset values, all of which hamper bank capacity to extend credit to firms. Credit availability to firms, especially small ones, declines, at a time when it is most needed (Brimmer 1992: 378; Anabtawi and Smith 1994). 
Sseyonga -What a Firm Takes to Compete in ...

Leaving the private sector to operate with the minimum state intervention may prove as disastrous as excessive state intervention, however. That is if the economic crisis that flustered ASEAN-4 (Indonesia, Thailand, Philippines, and Malaysia) is anything to go by (Macloud 1998; Hakimian 1998). Little state monitoring of actions and operations conducted by the private sector do not only have deleterious consequences for the enterprises, but can destabilize entire economies. Proper supervision of firms private and state owned, compliance with prudential requirements as regards trading arrangements especially those transactions denominated in foreign currencies, debt contracting, personnel management; and adherence to proper accounting principles to avoid indulgence in creative accounting practices can be done by discrete, proportional state intervention (Sheehey 1993). The state of course has to provide the infrastructure to begin with. This encompasses an efficient legal system with streamlined rules and guidelines and laws on patents and copyrights, independent judiciary to handle bankruptcy cases, conducive investment climate under convivial political atmosphere, and supportive fiscal and monetary policies (Hakimian 1998: 24-25).

\section{The Jinx in Winning Strategies Adopted Under Recession}

Companies with ample cash resources may be able to increase their market share in the long term, enabling them to charge higher prices to recoup losses incurred during the market penetration process.

Having the capability to survive in economic downturn, equips the firm with the capacity to perform even better under normal conditions. Management of firms that outperform others in economic slowdowns acquires the diversity of perspectives and knowledge vital for competing in hard times; provides the ground for developing and practicing competitive moves and maneuvers requisite to beat rivals; offers the opportunity to managers for improving their ability to manage the financial resources of the companies they lead, crucial for keeping their jobs and survival of companies; provides an invaluable addition to the company's repertoire of actions, and reactions necessary, to maintain the firm's edge over rivals, which can be referred to time and again.

A caveat is in order here, nonetheless. Relentless pursuit of the efficiencyis-king philosophy has the potential danger of delaying, even derailing the innovation process, with the consequence of reducing the very foundation of the industry's core competences; the products and services. Pursuing cutthroat competition unremittingly, may eventually lead to the demise of the entire industry as companies make cutbacks on all sources of fixed overhead costs including research and development expenses, recruitment, manpower training and development, the key pillars that sustain firm survival, let alone competitiveness. Outsourcing information technology may reduce short-term costs, and thus shores up quarterly earnings, and is darling of executives in hard times, yet it carries the danger of eroding the core competence inherent in operating in-house information systems in the long run (Lacity and Hierschein 1993: 76).

Some practices, though profitable, may violate fair trade practices, and thus may embroil the company in costly litigation, gobbling up much needed cash. The most vivid example is bundling of services, which though enhances firms' competitive advantage and enables firms to 
sail over hard and good economic conditions alike, may be regarded as a monopoly practice, which may bring dire consequences to the firm. So is the disposal of companies' products at lower than cost of production in foreign markets, which may invoke anti-dumping litigation. Environmental concerns may hamper economically feasible options. Thus, masterly of the situation is as good as keeping at the manager's finger tips, the legal, social, cultural and environmental implications of actions taken, in an economic boom and bust alike.

\section{Concluding Remarks}

If there is any lesson to be learnt from factors underlying the success of firms in conditions of economic contraction, it is the diversity of such factors. Success in downturns for one firm in one industry may be the harbingers of disaster for another firm in another industry. That is not to say, there are no common denominators. Success in a recession requires astute management with the skill and experience in a variety of competitive moves and maneuvers; adoption of low-cost-low price strategies; use of scenario planning rather than basing company actions on past but possibly nonrecurring gains; and having sufficient liquidity to take full advantage of opportunities availed by economic hardships. Better incorporation of information technology such as the internet in company's core competences enhances company leverage over rivals in good as well as hard times. Enhancing the firm knowledge management capability, as well as proper use of currency risk management methods to reduce, and if possible, eliminate exchange rate variability exposure add to the company's edge. Going global, in a smarter way, which involves the participation of local officials and entrepreneurs, non government organizations' activists, making use of existing infrastructure through establishing joint ventures with local businesses men in small but focused projects rather than investing billions in new but uncharted territories, and the investment of ample time in the understanding the customs, values, and traditions of local societies, all offer competitive advantages to the firm over rivals, especially in conditions of economic distress.. It is incontrovertible, however, that firm success must be backed by strong and appropriate macroeconomic management by governments with respect to fiscal, monetary and trade polices.

\section{Reference}

Anabtawi, I., and G. Smith. 1994. Macroeconomic modeling of money, credit and banking. Eastern Economic Journal 20(3): 275-290.

Anderson, E.W., C. Fournell, D. R. Lehman. 1994. Customer satisfaction, market share and profitability: Findings from Sweden. Journal of Marketing 58 (3): 53-66.

Amburgery, T.L., D. Kelly, and W.P. Barnett. 1993. Resetting the clock: The dynamics of organizational change and failure. Administrative Science Quarterly 38(1):51-73.

Ante, S.E. 2001. Simultaneous software. Business Week (August 27): 94-95.

Blau, P. M., and R. A. SchoerHerr. 1971. The Structure of Organization. New York. 


\section{Sseyonga -What a Firm Takes to Compete in ...}

Batten, J., R. Mellor, and V. Wan. 1993. Foreign exchange risk management practices and products used by Australian firms. Journal of International Business Studies 24 (3): 557-573.

Brimmer. A.F. 1992. Financial regulation and fragility of the banking system. Eastern Economic Journal 18 (4): 375-386.

Business Week (August 28). 2000: 39-129. The 21 Century Corporation: The great Transformation.

Business Week (August 28). 2000. The New Leadership: 57-61.

Business Week (August 28): 62-63. See the World, Erase its Borders.

Business Week (August 28). 2000: 64-66. Up from Bean Counter.

Business Week (June 4): 45-53. 2001. Microsoft: How it Became Stronger that Ever.

Business Week (September 24): 54-61. 2001. DELL the Conqueror: Now King of Cutthroat Pricing is Looking Beyond PCs.

Business Week (September 24): 62-63. 2001. From The Nexus of Lexus.

Byrne, J.A. 2001. Caught in the net. Business Week (August 20): 64.

Capelli, P., and R. Mc Kersie. 1978. Management strategies and the redesign of work Rules. Journal of Management studies 24 (5): 441-462.

Child, J. 1972. Organizational structure, environment and performance: The role of strategic choice. Sociology 6 (1): 1-22.

Cole D.C., and B.F. Slade. 1998. The Crisis and financial sector reform. ASEAN Economic Bulletin 15 (3): 338-246.

Covin J.G. 1991. Entrepreneurial versus conservative firms: A comparison of strategies and performance. Journal of Management studies 28: 439-462.

Donaldson, L. 1987. Strategy and structural adjustment to regain fit and performance: In defense of contingency theory. Journal of Management Studies 24 (1): 1-24.

Engardio, P. 2001. Smart globalization. Business Week (August 27): 82.

Ghemawat, P. 1991. The risk of not investing in a recession. SLOAN management Review 34 (2): 51-58.

Ginsberg, E.A., and E. Abrahamson. 1991. Champions of change and strategic shifts: The role of internal and external change advocate. Journal of Management Studies 28 (2): 16-172.

Ginsberg, E.A., and C. Fornburn. 1989. Shifting gears: Enabling change in corporate Aggressiveness. Strategic Management Journal: 299-308.

Hakimian., H. 1998. From east to west: Globalization, crisis, and economic reform. SOAS working paper series No. 82.

Haveman, H. A. 1992. Between a rock and a hard place: Organizational change and performance under conditions of fundamental transformation. Administrative Science Quarterly 37 (1): 48-72. 
Kerin, R.A., P.R. Kradajan, and R.A. Peterson. 1992. First-mover advantages: Synthesis, conceptual, framework and research propositions. Journal of Marketing 56 (4): 3352.

Kerstetter, J. Silicon seer. Business Week (August 30). 2001: 62.

Kimberley, J.R., and D. Rottman. 1987. Environment, organization and effectiveness: A biographical approach. Journal of Management Studies 24 (6): 595-622.

Lacity, M.C., and R. Hirschheim. 1993. The information system outsourcing Bandwagon. SLOAN Management Review (Fall): 73-86.

Lawless, M.W. 1991. Commodity bundling for competitive advantage: Strategy implications. Journal of Management Studies 28 (3): 267-280.

McLeod, R.H. 1998. Indonesia. In R.H. McLeod, and R. G. Rutledge (Ed.) East Asia in Crisis: From being a Miracle to Needing One?: 31-48.

Mintzberg, H. 1994. Rounding out the manager's job. SLOANManagement Review (Fall): 11-26.

Mintzberg, H. 1998. The innovative organization. The Strategy Process ( $3^{\text {rd }}$ ed.). Prentice Hall International Inc.: 309-323.

Miller,D., and M. Chen. 1994. Sources and consequences of competitive inertia: A study of U.S. airline industry. Administrative Science Quarterly 39 (1): 1-23.

Nasution, A. 1995. Lalu-lintas modal dan kebijakan moneter dalam era keterbukaan. Professorial Acceptance Speech Delivered (August 10). Indonesia: Indonesia University.

Osband, K. 1992. Economic crisis in a shortage economy. Journal of Political Economy 110 (4): 673-690.

Quelch, J.A., and L.R., Klein. 1996. The internet and international marketing. SLOAN Management Review (Spring): 60-75.

Quinn, J.B. 1995. Managing innovation: Controlled chaos. The Strategy Process (Collegiate edition). Prentice Hall International Inc.: 323-333.

Sadli, M. 1998. The Indonesian Crisis. ASEAN Economic Bulletin 15 (3): 272-280.

Sheehey, J.E. 1993. The effect of government size on economic growth. Eastern Economic Journal 19 (3): 321-327.

Shoemaker, P.J.H. 1995. Scenario planning: A tool for strategic thinking. SLOAN Management Review (Winter): 25-40.

Starbuck, W. A. 1992. Learning by knowledge in knowledge intensive firms. Journal of Management Studies 29 (6): 713-740.

A.Greve, and B.T. Hedberg. 1995. Responding to crises. In The Strategy Process (Collegiate edition). Prentice-Hall International: 387-401.

Suarez, F.T., M.A., Cusumano, and C.H. Fine. 1995. An empirical study of flexibility in manufacturing. SLOAN Management Review (Fall): 25-32.

Webber, J. 2001. Management lessons from the bust. Business Week (August 27): 58- 62. 